\title{
Half-Time at the Antitrust Modernization Commission
}

\author{
By Albert A. Foer*
}

\begin{abstract}
A S I WRITE IN THE LATE FALL of 2005, and edit in the late winter of 2006, the Antitrust Modernization Commission ("AMC" or "Commission") has lived approximately one-half of its statutory three-year life. We cannot yet predict what the AMC will report to Congress and the President in April 2007, but much can be said about what plays have been called in the first half and what is potentially at stake in the game. In this Article, I begin by describing the origins and structure of the AMC in Part I, briefly placing it into the context of previous blue ribbon antitrust study commissions. Part II depicts the AMC's accomplishments during the first half of its life, focusing on self-organization, the development of an agenda, and the various efforts to solicit information and advice from the public. Part III looks forward to the second half of the AMC's term, outlining what remains to be done and how the Commission is likely to go about doing it, with particular attention to seven substantive controversies. The Article concludes with a discussion of the factors that will determine whether the Commission's three years of labor will matter.
\end{abstract}

\section{The Rule Book}

The AMC is the brainchild of F. James Sensenbrenner, a Republican Member of Congress from Wisconsin who had recently become Chairman of the House Judiciary Committee when he introduced H.R. 2325 in 2001. ${ }^{1}$ No hearings were held on the bill, and it was generally assumed to be going nowhere. At the last minute Chairman Sensenbrenner attached it to an appropriations bill, and it sailed

* Albert A. Foer (A.B., Brandeis University; M.A., Washington University; J.D., University of Chicago) is the founder and President of the American Antitrust Institute, an independent non-profit research, education, and advocacy organization whose website is www.antitrustinstitute.org.

1. See Jaret Sieberg, Bill Proposes Review of Antitrust Laws, DeAL, Jun. 27, 2001, available at http://www.thedeal.com/servlet/ContentServer?pagename=TheDeal/TDDArticle/ StandardArticle\&bn=NULL\&c=TDDArticle\&cid=1003865119187 (available by subscription only) (copy on file with author). 
through unopposed-although without noticeable support from anyone other than the Chairman. ${ }^{2}$ The law therefore has no legislative history to speak of.

Sensenbrenner himself talked about the need to study the intersections of antitrust and (1) high technology, (2) intellectual property, and (3) international law. ${ }^{3}$ However, the legislation does not address which specific topics the AMC should take up. Rather, it sets forth four specific duties:

(1) to examine whether the need exists to modernize the antitrust laws and to identify and study related issues; (2) to solicit views of all parties concerned with the operation of the antitrust laws; (3) to evaluate the advisability of proposals and current arrangements with respect to any issues so identified; and (4) to prepare and to submit to Congress and the President a report [("the Report")]. ${ }^{4}$

The AMC has twelve members who were appointed by the President, the Senate, and the House, with an equal mix of Republicans and Democrats. ${ }^{5}$ Before appointing members, the appointers were required to consult with each other "to ensure fair and equitable representation of various points of view in the Commission." 6 However, there is no evidence that such a consultation occurred. In fact, it would be difficult to say that there are any Commissioners who represent the Federal Trade Commission ("FTC") or the Antitrust Division, ${ }^{7}$ the states, consumers, small business, or the plaintiffs' bar, to name but a few obviously missing stakeholders. While some of the Commissioners, or the firms that employ them, occasionally represent plaintiffs, and some of the Commissioners served in enforcement posts earlier in their careers, the Commission as a whole-while made

2. Antitrust Modernization Commission Act of 2002 ("The Act"), Pub. L. No. 107$273, \S \S 11051-60,116$ Stat. 1856 (to be codified at 15 U.S.C. $\$ 1$ note). The Act is subtitle D of the 21st Century Department of Justice Appropriations Act and was passed on November 2, 2002.

3. See Sieberg, supra note 1.

4. Antitrust Modernization Commission Act $\$ 11053$.

5. Four members were appointed by the President (two having to come from the "opposition party"); two by the Majority Leader of the Senate; two by the Minority Leader of the Senate; two by the Speaker of the House of Representatives; and two by the Minority Leader of the House. Id. $\$ 11054$.

6. Id. $\S 11054(\mathrm{~h})$.

7. When they were appointed, Makan Delrahim worked in the Senate and Deborah Majoras was in private practice. Delrahim subsequently became Deputy Assistant Attorney General for Antitrust, but in Fall 2005 joined a Washington, D.C. law firm. Majoras was required to step down from the AMC when she was appointed Chair of the FTC. Several Commissioners had earlier high-level experiences in the two federal antitrust agencies. Antitrust Modernization Comm'n, Commissioners \& Commission Staff Bios, http://www. amc.gov/bios.htm [hereinafter AMC Staff Bios] (last visited Feb. 7, 2006). 
up of esteemed and experienced antitrust experts-is dominated by people whose recent backgrounds strongly suggest a defense orientation. ${ }^{8}$

In an article drafted before the Commissioners were appointed, I offered four generalizations to be gleaned from the statutory framework of the AMC. ${ }^{9}$ First, because the statute provided almost no direction, it would be up to the Commission to define its own scope and priorities. ${ }^{10}$ Second, whether Congress would achieve its objective of a politically balanced and broadly representative Commission would depend as much on the appointments of staff and expert consultants as

8. The Commissioners and their affiliations are: Deborah A. Garza (Chair) (Fried, Frank, Harris, Shriver \& Jacobson, Washington, D.C.; former Chief of Staff in the Antitrust Division), Jonathan R. Yarowsky (Vice Chair) (Patton, Boggs, Washington, D.C. office; former General Counsel to the House Judiciary Committee), Bobby R. Burchfield (McDermott, Will \& Emory, Washington, D.C.; replaced Deborah Majoras (Jones Day, Washington, D.C.) after she was appointed to be Chair of the Federal Trade Commission)), W. Stephen Cannon (Constantine Cannon, Washington, D.C.; former General Counsel to Circuit City with substantial experience in the Antitrust Division and the Senate Judiciary Committee), Dennis W. Carlton (Economist, University of Chicago; Senior Managing Director, Lexecon, which-like the large law firms-most often represents large corporate antitrust defendants), Makan Delrahim (appointed while Chief Counsel to the Senate Judiciary Committee, but has since been Deputy Assistant Attorney General for Antitrust and is now with Brownstein, Hyatt \& Farber, Washington, D.C.), Jonathan M. Jacobson (appointed while at Akin Gump et al., but now at Wilson Sonsini Goodrich \& Rosati, New York), Donald G. Kempf, Jr. (appointed while Executive Vice President, Morgan Stanley, New York), Sanford M. Litvack (Hogan \& Hartson in Los Angeles; former Assistant Attorney General for Antitrust), John H. Shenefield (Morgan Lewis \& Bockius in Washington, D.C.; former Assistant Attorney General for Antitrust), Debra A. Valentine (Vice President, United Technologies; former General Counsel, FTC), and John L. Warden (Sullivan and Cromwell, New York). The Republican appointees are Cannon, Delrahim, Kempf, and Warden. Democratic appointees are Jacobson, Shenefield, Yarowsky, and Valentine. Presidential appointees are Garza, Carlton, Litvack, and Majoras (replaced by Burchfeld) (Carlton and Litvack represent the "opposition party"). Biographical information is available on the AMC website. See AMC Staff Bios, supra note 7.

A Washington Post article hinted at close relations between several of the Commissioners and the Microsoft Corporation and concluded, "The makeup of the panel and the questions it is examining, however, suggest that most of the focus will be on the needs of antitrust defendants, or potential defendants." Jonathan Krim, A Less-Public Path to Changes in Antitrust, WASH. Post, May 12, 2005, at E1, available at http://www.ffhsj.com/antitrust/ pdf/alert_110901.pdf.

9. Albert A. Foer, Putting the Antitrust Modernization Commission into Perspective, 51 Buff. L. Rev. 1029, 1031-32 (2003) [hereinafter Foer, Perspective]. This article attempted to suggest what could be learned from important predecessor blue ribbon antitrust study commissions, including the 1938-1941 Temporary National Economic Commission, the 1955 Attorney General's National Committee to Study the Antitrust Laws, the 1969 White House Task Force on Antitrust Policy, the 1979 National Commission to Review Antitrust Law and Procedures, and the 1998 International Competition Policy Advisory Committee.

10. Id. at 1031 . 
on the appointment of Commissioners. ${ }^{11}$ Third, the critical appointment would be that of the Chairperson, who is empowered to control the Executive Director and the staff. As Commission members are likely to be very busy part-timers, the staff would probably play a driving role on developing the agenda, priorities, spending choices, and Report wording. ${ }^{12}$ Fourth, the ability to hold a large number of meetings, hear substantial amounts of testimony, retain specialized experts, and recruit a top quality staff would be influenced by the funding. Congress authorized a total of four million dollars for three years, which will presumably be doled out in annual appropriations. ${ }^{13}$

This is not the first blue ribbon antitrust study commission. ${ }^{14}$ Indeed, over the past seventy years, a new commission seems to have been born roughly once every generation. Some commissions have been established by Congress, ${ }^{15}$ while some have been established by the Executive Branch. ${ }^{16}$ Their durations and resources have widely varied. Their assignments have sometimes been broad and sometimes been narrow. ${ }^{17}$ Rarely have they had an immediate impact on legislation, but sometimes their long-term impact has been significant. ${ }^{18}$ For example, the Temporary National Economic Commission ("TNEC") focused its attention on the role of industrial concentration, leading to the Celler-Kefauver amendments to the Clayton Act nine years later. ${ }^{19}$

The TNEC membership was evenly balanced between the Administration and Congress. ${ }^{20}$ The $\mathrm{AMC}$, on the other hand, is made up of experts but does not include any Senators or members of Congress. When the AMC Report ("Report") is eventually submitted, there will

11. Id.

12. Id. at 1031-32.

13. Id.

14. See id. at 1029.

15. For example, the Temporary National Economic Commission (1938-1941). See id. at 1032-36.

16. For example, the National Commission for Review of Antitrust Laws and Procedures (1977-79). See id. at 1041-44.

17. The National Commission for Review of Antitrust Laws and Procedures (1977-79) was ordained to cover only two main policy areas: the unreasonable protraction of complex antitrust cases and reevaluation of existing immunities and exceptions from antitrust laws. On the other hand, the White House Task Force Report on Antitrust Policy (1967-69) was an open-ended vehicle aimed at information gathering and identification of the most important areas for reform. See id. at 1039, 1042.

18. See id. at 1046-47.

19. See Rudolph J.R. Peritz, Competition Policy in America: History, Rhetoric, Law 158-59 (rev. ed. 2000).

20. See Foer, Perspective, supra note 9, at 1033. 
be no politicians with any foreseeable buy-in to the Report, other than Congressman Sensenbrenner. However, Congressman Sensenbrenner is not a member of the AMC and, because of term limits adopted by the Republicans, will not even be Chairman of the House Judiciary Committee when the Report is submitted.

\section{The Game Plan for the First Half}

\section{A. Getting Organized}

The first task of any study commission is to make the transition from statutory framework to physical reality. Appointments to the AMC were required to be made within sixty days of enactment of the law, and the three-year clock was to start running with the first meeting of the Commission. ${ }^{21}$ The AMC appointment process was apparently not on the top of any politician's priority list because the appointments were not completed for sixteen months. ${ }^{22}$ Indeed, the Commission's charter could not be filed until April 2, 2004. On June 28, 2004, the AMC issued its first press release, announcing the identification of the Chairperson (Deborah A. Garza) and the Vice Chairperson (Jonathan R. Yarowsky), the membership, and the schedule for its first public meeting. ${ }^{23}$ Ms. Garza is a partner in the Washington D.C. office of Fried Frank. ${ }^{24}$ The press release also announced

21. Antitrust Modernization Commission Act of 2002 ("The Act"), Pub. L. No. 107273, $\S 11054$ (e) , 11058, 116 Stat. 1856, 1859 (to be codified at 15 U.S.C. $\S 1$ note). The charter is found at Antitrust Modernization Comm'n, Charter, http://www.amc.gov/pdf/ charter/amc_charter.pdf (last visited Feb. 7, 2006). The Commission goes out of existence thirty days after the Report is submitted. $I d . \S 11059$.

22. The last appointments were announced by the President on March 5, 2004 (Dennis W. Carlton of Illinois, Deborah A. Garza of the District of Columbia to be Designate Chairman upon appointment, Sanford M. Litvack of New York, and Deborah P. Majoras of Virginia). See Press Release, Office of the Press Sec'y, Personnel Announcement (Mar. 5, 2004), available at http://www.whitehouse.gov/news/releases/2004/03/20040305-5.html (last visited Feb. 7, 2006).

23. See Press Release, Antitrust Modernization Comm'n, Antitrust Modernization Commission Announces First Public Meeting and Appointment of Executive Director and General Counsel (June 28, 2004), available at http://www.amc.gov/pdf/news/press_release040628.pdf.

24. When Ms. Garza joined Fried Frank in 2001, Charles (Rick) Rule, head of Fried Frank's antitrust practice said:

I'm thrilled that Deb has chosen to join the firm. She is one of the best antitrust lawyers of her generation. At the Justice Department, she helped to develop enforcement policies, particularly in the area of merger review, that guide the Antitrust Division today. In private practice, she has been involved in some of the major antitrust matters of the past two decades, including the representation of Exxon in its merger with Mobil and the representation of the National Football League in its landmark litigation with the United States Football League. By at- 
the appointment of Andrew J. Heimert as Executive Director and General Counsel. ${ }^{25} \mathrm{Mr}$. Heimert had been an attorney in the FTC's Office of Policy and Coordination within the Bureau of Competition. The first public meeting was held on July $15,2004,{ }^{26}$ and the Commissioners announced that the final Report would be submitted in April 2007.27

Once the Chair had appointed Heimert as Executive Director, the AMC needed to complete a variety of logistical tasks, such as the hiring of staff, finding a location for a physical office, compliance with the usual range of administrative filings, and establishment of a website. ${ }^{28}$ Staff biographies may be found on the website. ${ }^{29}$

The first meeting opened with remarks by Congressman Sensenbrenner, the legislative father of the Commission. ${ }^{30}$ In this and subsequent meetings, the AMC created "working groups" to suggest topics for study and called for public comments once the topics were selected. On January 8, 2005, the Commission identified an initial slate of twenty-five topics for study. ${ }^{31}$ These selections were eventually revised, and individual Commissioners were named to work on particu-

tracting Deb to become a leader in our antitrust department, Fried Frank has taken a major step in its effort to build the preeminent antitrust practice.

Press Release, Fried Frank, Garza Joins Fried Frank as Antitrust Partner (Feb. 20, 2001), available at http://www.ffhsj.com/pressreleases/garza.htm.

25. The Chair appoints the Executive Director, subject to approval by the Commissioners. Antitrust Modernization Comm'n Act $\$ 11056(\mathrm{a})(1)$. There is nothing on the record indicating that this appointment came to a vote.

26. See Press Release, Antitrust Modernization Comm'n, Antitrust Modernization Commission Holds First Public Meeting, Seeks Public Comment on Topics for Study, and Unveils Website (July 16, 2004), available at http://www.amc.gov/pdf/news/press_release 040716.pdf.

27. Id.

28. Antitrust Modernization Comm'n, Home Page, http://www.amc.gov [hereinafter AMC Home Page] (last visited Feb. 7, 2006).

29. The staff consists of the Executive Director and General Counsel (Andrew J. Heimert), two counsels (William F. Adkinson, Jr. and Todd Anderson), an economist (Michael W. Klass), two senior advisors (William E. Kovacic and Alan J. Meese), a law clerk (Hiram Andrews), and a paralegal (Kristin M. Gorzelany). Mr. Anderson departed at the beginning of 2006. Mr. Kovacic was nominated and confirmed for a Republican seat on the Federal Trade Commission and apparently played only a limited role on the AMC staff. AMC Staff Bios, supra note 7.

30. The transcript of this meeting may be found at Antitrust Modernization Commission, Public Meeting, available at http://www.amc.gov/pdf/meetings/transcript040715. pdf. Records relating to all public meetings are available on the AMC's website. Antitrust Modernization Comm'n, Commission Meetings, http://www.amc.gov/commission_meetings.htm.

31. See Press Release, Antitrust Modernization Comm'n, Antitrust Modernization Commission Selects Initial Slate of Issues for Study (Jan. 18, 2005), http://www.amc.gov/ pdf/news/press_release050119.pdf. 
lar "study groups." 32 The Chair did not appoint official leaders of any study group. ${ }^{33}$ The function of the study groups was to review the testimony and public comments on the specific topics and to make recommendations to the full AMC as to what policies should be adopted for the final Report. ${ }^{34}$ While the Commission as a whole was shaped to function in accordance with the Federal Advisory Committee $\mathrm{Act}^{35}$ ("FACA"), the Commission initially took the position that study groups are not covered by the Act and can therefore meet and act in private. When challenged by the American Antitrust Institute, however, the Chair, speaking for the Commission, advised that during the second half of the AMC's life, the study groups would not deliberate on policy issues or make recommendations to the Commission. ${ }^{36}$

\section{B. Developing the Agenda}

How might a study commission, whose only assignment is to make recommendations relating to the possible modernization of antitrust, structure its agenda? Answering this question was the first major task of the AMC. One approach would be to begin with extensive data collection. "Modernization" presumably implies that some circumstances of importance to antitrust have changed and that these changes now require antitrust to also change by taking "modern" developments into account. Thus, one might start by comparing relevant aspects of the past political economy with the present political economy and perhaps with predictions about the future. Only after this task had been accomplished would the Commission then turn to policy recommendations. This approach was used by the TNEC, whose multivolume picture of the economy during the Great Depression was

32. See Memorandum from Andrew Heimert, Executive Dir. \& Gen. Counsel, Antitrust Modernization Comm'n, to All Commissioners (Feb. 25, 2005), available at http:// www.amc.gov/pdf/meetings/list_of_study_groups_rev.pdf (regarding "Study Groups").

33. At any early stage, these were deemed "working groups," and leaders were appointed, but once the specific topics were selected for study, the AMC's membership was assigned to leaderless "study groups." To not appoint what would in effect be subcommittee chairs might be viewed as a management decision to retain centralized control. In any event, it deprived the study groups of a formal leader with responsibility for developing and shepherding a program.

34. See Antitrust Modernization Comm'n, Transcript of Meeting 5 (Jan. 13, 2005), available at http://www.amc.gov/pdf/meetings/transcript050113.pdf [hereinafter AMC Meeting Transcript].

35. Federal Advisory Committee Act, 5 U.S.C. app. $\$ \S 1-16$ (2000).

36. See Memorandum from Albert A. Foer, President, Am. Antitrust Inst., to Am. Antitrust Inst. Advisory Bd. (Feb. 28, 2006), available at http://www.antitrustinstitute.org/recent2/487.pdf (last visited Mar. 8, 2006) (regarding "Transparency and Process at the Antitrust Modernization Commission"). 
called by one historian "the most dramatic and sweeping investigation of American industry ever undertaken." 37 This model of surveying the landscape is what the author recommended to the AMC. ${ }^{38}$

Nevertheless, the TNEC did not have an immediate impact. As Alan Brinkley put it, "It had gathered the data. It would be up to others to decide how to use it." 39 Thus, a different approach-targeting delimited objectives-might seem more compelling to those who know what they want to achieve and are anxious to show results. Prior antitrust study commissions, such as the National Commission for Review of Antitrust Laws and Procedures (1977-79) and the International Competition Advisory Committee (1998-2000), are examples of the use of the targeting approach, in that their charters were more carefully delimited. The AMC, so lacking in statutory direction, decided to define its agenda by selecting for itself the specific questions that it would attempt to answer.

At its first public meeting on July 15, 2004, the AMC decided to solicit public comments on what issues it should study. ${ }^{40}$ While waiting for comments, it would reach out to the "consumer, business, academic, legal, and enforcement communities" 41 for further enlightenment. At its second meeting-not scheduled until January 10, 2005it would decide what issues to study. Someone must have noticed that the clock was ticking, because the next meeting was actually held on October 20, 2004. ${ }^{42}$ At this meeting, eight working groups were established, and each Commissioner was appointed to serve on two or more groups. ${ }^{43}$ The Executive Director reported that more than thirty-five individuals and organizations contributed public comments. ${ }^{44}$ Finally, the AMC determined that the working groups, each

37. Susan Wagner, The Federal Trade Commission 81 (Ernest S. Griffith \& Hugh Langdon Elsbree eds., 1971).

38. Foer, Perspective, supra note 9, at 1047-50.

39. Alan Brinkley, The End of Reform 127 (Alan A. Knopf 1995) (1966).

40. See Memorandum from Deborah Garza et al., to Comm'rs, Antitrust Modernization Comm'n (July 14, 2004), available at http://www.amc.gov/pdf/news/comments_proc _memo2.pdf (regarding "Proposed Process for Soliciting Public Input and Timeline for Preliminary Identification of Issues for Further Commission Study").

41. Id.

42. Antitrust Modernization Comm'n, Meeting Minutes (Oct. 20, 2004), available at http://www.amc.gov/pdf/meetings/minutes041020.pdf [AMC Meeting Minutes].

43. The working groups were for: Mergers, Acquisitions and Joint Ventures; Civil Procedures and Remedies; Criminal Procedures and Remedies; Immunities and Exemptions; Regulated Industries; Intellectual Property; International Antitrust; and Single Firm Conduct. Antitrust Modernization Comm'n, Working Group Assignments, available at http:// www.amc.gov/pdf/meetings/wgassignmentsoutline.pdf.

44. AMC Meeting Minutes, supra note 42. 
under an appointed leader, would circulate recommendations to the full Commission by December 17. The AMC would vote upon these recommendations at the next meeting, now scheduled for January 2005.45

At last, on January 13, 2005, the Commissioners took up a litany of specific questions prepared by the various working groups. ${ }^{46}$ After introductions by the working group leaders, the Commissioners voted to take up twenty-nine questions, ranging from broad and controversial questions, such as "What should be the remedies and legal liabilities in private antitrust proceedings?" and "How does the current intellectual property regime affect competition?" to relatively simple and uncontroversial questions, such as "Should section 3 of the Robinson-Patman Act (relating to criminal penalties) be repealed?" A few questions were deferred for further discussion.

The next public meeting, on March 24, attracted eight Commissioners and an audience of fifty, and it lasted a mere twenty-five minutes. ${ }^{47}$ It had been scheduled to deal with only two matters that had been deferred. ${ }^{48}$ The first matter was whether to study the topic of timetables for criminal and civil non-merger antitrust investigations by the FTC and Department of Justice ("DOJ"). ${ }^{49}$ The Commissioners voted not to make this a separate issue for study, but to address the issue in the final Report they will submit to Congress. ${ }^{50}$

The second question was somewhat more sensitive. Assistant Attorney General Hewitt Pate had sent a letter to the AMC urging it to undertake or design a comprehensive empirical study of the costs and benefits of antitrust enforcement. ${ }^{51}$ The Commissioners found themselves in the position of not wanting to offend the DOJ but, having already publicly committed themselves to an overwhelming menu of tasks, were reluctant to also undertake the type of comprehensive study being proposed. The Commissioners voted unanimously not to undertake the DOJ study, but rather to "undertake more limited empirical studies where appropriate as part of its consideration of issues

45. Id.

46. See Antitrust Modernization Comm'n, Meeting Minutes (Jan. 13, 2005), available at http://www.amc.gov/pdf/meetings/minutes050113.pdf.

47. See Antitrust Modernization Comm'n, Meeting Minutes (Mar. 24, 2005), available at http://www.amc.gov/pdf/meetings/minutes050324.pdf.

48. Id.

49. Id.

50. Id.

51. Id. 
selected for further study and identify areas in which further empirical research could be useful." 52

During the ensuing period, the AMC reviewed the approved study questions and reorganized the questions under slightly different topics, and "study groups" replaced "working groups" with Commissioners each assigned to one or more study groups. Each group produced a "study plan" that was reviewed and voted upon at the fifth public meeting on May 9.53 The adoption of nine study plans followed (Enforcement Institutions, Exclusionary Conduct, Immunities and Exemptions, International Antitrust, Merger Enforcement, New Economy, Regulated Industries, Remedies, and Robinson-Patman), with an agreement to publish them in the Federal Register with a request for public comments. ${ }^{54}$

Each study plan listed the issues adopted for study and a series of questions for public comment. For example, the Enforcement Institutions Study Plan posed three questions about dual federal merger enforcement, four questions about differential merger enforcement standards, four questions about the allocation of merger enforcement among states, private plaintiffs, and federal agencies, and three questions about the role of states in enforcing non-merger antitrust laws. ${ }^{55}$ The plan also called for four (or possibly five) separate hearings with panels of witnesses. ${ }^{56}$ The AMC adopted a tenth study plan, Criminal Issues, at the sixth meeting on July 28, 2005. ${ }^{57}$ Altogether, the ten study plans contained 176 separate questions and called for twentynine separate hearings.

The issues not placed on the table are as important as those that were. This Article has already shown that the AMC rejected both a large-scale view of antitrust within the context of a changing political economy and comprehensive empirical projects. ${ }^{58}$ Also, the AMC did not take up a number of important and hotly debated questions in the

52. Id.

53. See Antitrust Modernization Comm'n, Meeting Minutes (May 9, 2005), available at http://www.amc.gov/pdf/meetings/minutes050509.pdf.

54. Id.

55. See Memorandum from Enforcement Institutions Study Group to All Commissioners, available at http://www.amc.gov/pdf/meetings/enforcement_institutions_study_plan. pdf (regarding "Enforcement Institutions Study Plan").

56. Id.

57. See Antitrust Modernization Comm'n, Meeting Minutes (July 28, 2005), available at http://www.amc.gov/pdf/meetings/Minutes050728.pdf.

58. See supra text accompanying note 38 . 
antitrust community relating to the purposes and goals of antitrust, 59 the role of concentration, ${ }^{60}$ how to deal with power buyers, ${ }^{61}$ the problem of patent ambush, ${ }^{62}$ and reform of the antidumping laws. ${ }^{63}$

From April 2, 2004 (the filing of the charter) until May 9, 2005 (approval of the study plans), more than one-third of the AMC's life had been spent on organization and deciding what issues to study. While the result cannot be evaluated until after the Report is written, one may question whether more efficient use could have been made of the first year and whether the particular set of questions adopted represents the best strategy for determining what, if anything, needs to be "modernized."

Insofar as has been revealed in public meetings, the approach selected by this panel of eleven lawyers and one economist is heavily legalistic. The Commission itself has neither undertaken nor contracted for new research. ${ }^{64}$ If new information is to be taken into account, it will probably have to be furnished by the public, through formal comments or testimony. According to AMC staff, the single example of the Commission formally reaching out to stimulate volunteer consultants to produce desired research was the assignment given to Darren Bush (University of Houston Law Center), Gregory Leonard (NERA Economic Consulting), and Stephen Ross (University of

59. For a review of the debate over the proper goals of antitrust, see Albert A. Foer, The Goals of Antitrust: Thoughts on Consumer Welfare in the U.S. (Am. Antitrust Inst., Working Paper No. 05-09, 2005), available at http://www.antitrustinstitute.org/recent2/350.pdf [hereinafter Foer, Goals of Antitrust].

60. For a review of current issues relating to the role of concentration, see Press Release, Albert A. Foer, President, Am. Antitrust Inst., AAI Issues Statement on Mergers and Concentration Critical of Current Policies (Feb. 10, 2004), available at http://www.antitrust institute.org/recent2/296.cfm.

61. The AAI conducted a symposium on power buyers and antitrust, the papers of which were presented in a symposium issue of the A.B.A.'s Antitrust Law Joumal. For an overview, see Albert A. Foer, Introduction to Symposium on Buyer Power and Antitrust, 72 ANTITRUST L.J. 505, 505-08 (2005).

62. See Letter from Robert Barr, Vice President, Worldwide Patent Counsel, Cisco Sys., \& Gil Ohana, Dir., Antitrust \& Competition, Cisco Sys., to Andrew J. Heimert, Executive Dir. \& Gen. Counsel, Antitrust Modernization Comm'n (Jan. 7, 2005), available at http:// www.amc.gov/comments/pub_submissions/cisco.pdf.

63. See Am. Antitrust Inst., Comments of the American Antitrust Institute WorkING Group ON INTERNATIONAL Issues 4 (2005), available at http://www.amc.gov/public_ studies_fr28902/international_pdf/050715_AAI_International.pdf.

64. Prior blue ribbon antitrust commissions had sometimes contracted out for specific research or had been able to assign specific research to government agencies with expertise. The AMC's statute permitted these strategies, at the discretion of the Commission. Antitrust Modernization Commission Act of 2002, Pub. L. No. 107-273, $\S \$ 11056$ (b), 11507 (d), 116 Stat. $1856,1858-59$ (to be codified at 15 U.S.C. $\$ 1$ note). 
Illinois College of Law) to prepare a framework for policymakers to analyze proposed and existing antitrust exemptions and immunities. ${ }^{65}$

\section{The Role of the Public}

The AMC's outreach until this point in time has reflected four phases: the informal seeking of suggestions from antitrust notables, a request for public comments on setting the agenda, the request for public comments on topics selected by the Commission for study, and public hearings.

\section{Informal Outreach}

Prior to its first public meeting, the Commission determined that it would initially reach out informally to the antitrust community for ideas about how to proceed and what topics to focus on. I was personally scheduled to visit with the Commission at its new offices for such a discussion. It turned out to be a one-hour unstructured conversation that included the Executive Director and three Commissioners who participated by conference call. There appears to be no public record of who else participated in this initial outreach program, nor is it clear whether other conversations were more productive than mine.

\section{Request for Comments on the Agenda}

On July 23, 2004, the Commission asked for public comments by September 30 on what issues it should study. ${ }^{66}$ Thirty-eight comments were received.67 Some comments, like those of the American Antitrust Institute ("AAI") and the American Bar Association ("ABA") Antitrust Section, ${ }^{68}$ were broadly based; others dealt with specific issues of particular interest to the authors, such as the American Homeowners Grassroots Alliance, which was principally concerned with antitrust issues relating to the real estate industry, or the Americans for Tax Reform. " $[A]$ ntitrust laws, if they ever served a useful purpose, now only

65. This framework was presented at hearings on December 1,2005 , to elicit reaction from panelists and Commissioners. Antitrust Modernization Comm'n, Commission Hearings, Statutory Immunities and Exemptions (Dec. 1, 2005), available at http://www.amc. gov/commission_hearings/statutory_immunities_exemptions.htm.

66. Antitrust Modernization Commission Request for Public Comment, 69 Fed. Reg. 43,969 (July 23, 2004).

67. Antitrust Modernization Comm'n, List of Public Comments, http://www.amc. gov/commission_study_issues.htm.

68. Ronan P. Harty, The Antitrust Modemization Commission: An Introduction, ANTITRust Source, Nov., 2004, at 3, available at http://www.abanet.org/antitrust/source/11-04/Nov 04-Harty1129.pdf. 
exist to stifle productivity growth and development of new products and services." 69

After the Commission made its initial cut on topics for study, another eleven public comments were submitted, unsolicited. Five of these urged the Commission to reconsider its decision not to include the patent ambush issues. ${ }^{70}$ Five urged the Commission not to attempt to reevaluate antidumping laws. ${ }^{71}$ The eleventh criticized the Commission for not being responsive to public comments. ${ }^{72}$ The Commission did respond, however, to the politicians' concerns that it lacked both the specific expertise and the statutory mandate to take up antidumping, by removing this subject from the agenda of topics.

\section{Request for Public Comments on Substance}

On May 19, 2005, the AMC requested that the public provide comments by June 17 , July 1 , or July 15,2005 , depending on the topic for the first nine study plans. ${ }^{73}$ In effect, this meant that an organization wishing to respond to all 176 questions in a timely fashion would have no more than four to six weeks to prepare all of its comments. Given that most organizations would require time to do research, write thoughtful comments, and clear them through any sort of committee or internal review process, this hardly seemed to be a welcoming invitation.

Ninety-four comments were filed in a timely fashion, with another twenty-nine filed by the end of October. ${ }^{74}$ However, these numbers are misleading. Sixty-one of the 110 filings related to the Immunities and Exemptions Study Plan, and most of these were submitted by industries wishing to maintain their own current exemptions and immu-

69. Letter from Grover G. Norquist, President, Ams. for Tax Reform, to Deborah A. Garza, Chairman, Antitrust Modernization Comm'n (Sept. 9, 2004), available at http:// www.amc.gov/comments/americanstaxreform.pdf.

70. These comments were submitted by the AAI, Sun Microsystems, Cisco Systems, Hewlett-Packard, and International Business Machines. Antitrust Modernization Comm'n, Public Comment, http://www.amc.gov/public_submissions.htm (last visited, Feb. 7, 2006).

71. These comments were submitted by Senators Specter and DeWine, Congressman English, Congressmen Rangel and Conyers, Senator Byrd, and the Committee to Support United States Trade Laws. Id.

72. Letter from Carl Lundgren, Relpromax Antitrust Inc., to the Antitrust Modernization Comm'n (Jan. 11, 2005), available at http://www.amc.gov/comments/pub_submissions/relpromax.pdf (last visited Feb. 7, 2006).

73. Antitrust Modernization Commission Request for Public Comment, 70 Fed. Reg. 28,902, 28,902-07 (May 19, 2005).

74. Antitrust Modernization Comm'n, Public Comment, http://www.amc.gov/ public_studies.htm. 
nities. ${ }^{75}$ Moreover, of the remaining submissions, ten were submitted by the AAI, four were submitted by the International Chamber of Commerce, and three were submitted by sections of the ABA. ${ }^{76}$

The AAI, an independent non-profit organization, had prepared for the AMC by establishing volunteer working groups to parallel the AMC's study groups. With a streamlined internal review process and the flexibility to allow each working group to submit comments under its own identification, the AAI could address in some depth nearly all of the questions posed by the AMC. ${ }^{77}$

It is anticipated that the Antitrust Section of the ABA will provide comments comparable in breadth. Working groups were established by the Antitrust Section to comment on various topics, but because the ABA's internal procedures proved sufficiently cumbersome, the first comments did not arrive at the AMC before late October 2005. ${ }^{78}$ An example would be the fourteen page, single-spaced filing on Octo-

75. Id.

76. Id.

77. The Author served on every AAI working group and edited all papers to provide consistency both in formatting and in overall substantive positioning. Each paper represented a consensus of its working group, ascertained through telephone conferences and e-mail exchanges, but there were no votes taken, and no one member should be assumed necessarily to agree with all statements in the comments. The timing imposed by the AMC severely limited the potential for in-depth legal or economic research. Thus, the only AAI comment that provided new empirical data was the Comment on Criminal Remedies, in which attention was called to information that had recently been published by Professors John Connor and Robert Lande (two members of a working group chaired by attorney Kenneth Adams), showing that the harm caused by cartel pricing was significantly greater than previously thought. Am. ANtrtrust Inst., Comments of THE AMErican ANTITrust INSTITUTE WORKING GROUP ON CRIMINAL. ReMEdies (2005), available at http://www.amc.gov/ public_studies_fr28902/criminal_pdf/050930_AAI_Criminal_Remedies.pdf.

For a flavor of these comments, see, for example, AM. ANTItrust Inst., Comments of the American ANTITRUSt Institute's Working Group on the New Economy (2005), available at http://www.amc.gov/public_studies_fr28902/new_economy_pdf/050715_AAI-New _Economy.pdf.

The working group, which included at least four antitrust law professors who teach courses on high technology or intellectual property law, was chaired by Professor Rudolph Peritz of the New York Law School. The other members were Joseph Bauer (law professor, Notre Dame), Michael Carrier (law professor, Rutgers, Camden), Albert Foer (attorney, AAI), Philip Nelson (economist, Economists, Inc.), Roger Noll (economist, Stanford), Mark Patterson (law professor, Fordham), Douglas Rosenthal (attorney, then with Sonnenschein, Nath \& Rosenthal), Jonathan Rubin (attorney and economist, AAI), F.M. Scherer (economist, Harvard), Robert Skitol (attorney, Drinker Biddle \& Reath), and Philip Weiser (law professor, University of Colorado). Id.

78. Letter from Am. Bar Ass'n, Section of Antitrust Law, to Antitrust Modernization Comm'n (Oct. 19, 2005), available at http://www.amc.gov/public_studies_fr28902/enforcement_pdf/051019_ABA_Govt_Enf_States_Roles-Enf_Inst.pdf (regarding "Comments Regarding Government Enforcement Institutions: The Enforcement Role of the States with Respect to Federal Antitrust Laws"). 
ber 19 by Section Chairman Donald C. Klawiter, titled "The Enforcement Role of the States with Respect to Federal Antitrust Laws." 79 On two of the more controversial issues addressed, the Antitrust Section's comments can be described as mild. "Absent a valid empirical basis," the Antitrust Section stated that it was "unwilling to recommend dramatic changes to the system of dual federal-state merger enforcement or to discount the criticisms of the system as it currently operates." 80 On the question of whether private enforcement should continue to be available to challenge mergers, the Antitrust Section suggested that the AMC "should not take any action to encourage or discourage any change to the system." 81

\section{Hearings}

As of the end of October 2005, the AMC had held hearings on six topics: Indirect Purchaser Actions, the Robinson-Patman Act, Civil Remedies Issues, the State Action Doctrine, Exclusionary Conduct, and State Enforcement Institutions. ${ }^{82}$ The AMC scheduled nine additional hearings before the information phase of the Commission's planned activity ends in January, 2006: Criminal Remedies, Federal Enforcement Institutions, New Economy, Merger Enforcement, Government Civil Remedies, Statutory Immunities and Exemptions, Regulated Industries, Noerr-Pennington Issues, and International Issues. ${ }^{83}$ The original plan called for twenty-nine hearings, which was probably twice as many as the Commissioners could actually handle, considering their on-going full-time professional responsibilities.

The typical AMC hearing involves a panel of four witnesses seated at a table facing the arrayed Commissioners. After a brief welcome from Chairperson Garza, the four witnesses, whose written statements are distributed beforehand, are each given five minutes to summarize their statements. The AMC designates one Commissioner as the lead questioner. After he or she has asked a series of questions, every other Commissioner is provided time to ask questions of any or all of the panelists. Similar to an appellate judge, questioning is often the way a Commissioner signals his or her perspective. However, thus far it has

79. Id.

80. Id. at 1 .

81. Id. at 3.

82. See Antitrust Modernization Comm'n, Hearings, http://www.amc.gov/commission_hearings/pdf/Hearings_Schedule.pdf (revised Oct. 17, 2005).

83. Id. For a timetable of the Commission's activities, see Antitrust Modernization Comm'n, Timetable, http://www.amc.gov/pdf/meetings/amc_timeline050330.pdf (last visited Feb. 7, 2006). 
proven difficult to predict where most Commissioners will come out when votes are eventually taken.

A hearing usually lasts two hours. The full transcript is published after some delay and editing on the AMC's website. ${ }^{84}$ With only four witnesses on a given topic, all viewpoints will obviously not be heard. Although the Commission has attempted to construct panels that represent several different constituencies in a generally balanced way, some efforts (e.g., exclusionary conduct and mergers) appear to have been less successful than others (e.g., treble damages).

By and large, very little if any "new" information has thus far been provided at the hearings. Instead, they are primarily occasions for well-informed advocates to promote previously developed positions relating to the matters before them. Some Commissioners (notably John Shenefield, who had chaired an earlier blue ribbon antitrust study commission) have made it a point to illuminate areas of consensus and difference within the panels.

Thus, during the first half of its statutory life, the AMC organized itself, developed an agenda, obtained written public comments, and conducted various hearings. No policy recommendations had been decided, and it appeared that a lot of heavy lifting lay ahead.

\section{The Second Half}

\section{A. The Timetable}

As the Commission returns to the field to play the second half, what remains to be accomplished? By the end of February 2006, the staff is expected to have compiled summaries of the research and information gathered. ${ }^{85}$ From March through May, the study groups and staff will prepare options for recommendations, and the Commission will begin meeting to deliberate on findings and recommendations. ${ }^{86}$ A draft Report and recommendations are anticipated to be completed in August, and the Report should be finalized in December. ${ }^{87}$ The final printed Report is scheduled for release on April 2, 2007.

Among the important procedural questions that still need to be answered are: (1) Will the study group meetings in which recommen-

84. AMC Home Page, supra note 28.

85. These plans were announced by the Chair at the January 13, 2005 meeting. See Antitrust Modernization Comm'n Meeting Transcript, supra note 34.

86. Id.

87. Id. 
dations are initially formulated and debated be open to the public?, (2) When will the Report drafts be released to the public (and will they be released as soon as prepared or all at once)? (3) Will the public have an opportunity for meaningful input once draft materials are available?, and (4) How will the Report handle dissents and individual statements by Commissioners?

\section{B. What Is at Stake?}

Out of the 176 questions targeted by the Commission, a few clusters are likely to prove most controversial and potentially important for the future of antitrust. I will call attention to seven of these.

\section{Role of the States}

The role of the state Attorneys General as antitrust enforcers has a long history, going back before the Sherman Act ${ }^{88}$ in some states. However, it became much more salient during the Reagan Administration, a period when federal antitrust was in severe retrenchment. The fact that many of the states disagreed with the DOJ (not to mention Microsoft Corp.) in this generation's landmark monopolization case led to complaints that the states were an unnecessary complication and that they should be made to bow out of any cases involving interstate commerce. In the alternative, the states should bow out of any cases in which the federal antitrust enforcers had reviewed a matter or, had taken formal enforcement action. ${ }^{89}$

State representatives were rather pointedly left off of the AMC and have no obvious representative within the membership. Recognizing this disadvantage, the states and their coordinating arm, the National Association of Attorneys General, have been gathering data to demonstrate their importance within the overall scheme of antitrust enforcement and that the system is not broken. Some of this information was presented by Professor Harry First in his testimony to the Commission on October $26 .{ }^{90}$ Based on questioning by the Commissioners, one could surmise that most at risk may be the states' jurisdic-

88. The Sherman Act is codified at 15 U.S.C. $\$ \$ 1-7$. For state histories, see Martin J. Sklar, The Corporate Reconstruction of American Capitalism, 1890-1916, at 93-105 (1988).

89. See, e.g., Richard A. Posner, Antitrust Law 281 (2d ed. 2001).

90. Allocation of Antitrust Enforcement Between the States and the Federal Government: Hearing Before the Antitrust Modernization Comm'n (2005) (statement of Harry First, Professor of Law, N.Y. Univ. Sch. of Law), available at http://www.amc.gov/commission_hearings/pdf/ Statement-First.pdf. This presentation can be considered an exception to the generalization that very little "new" information has been provided to the AMC by witnesses. 
tion over mergers impacting more than one state, which is to say, most mergers.

The AAI working group advocated that the states maintain their current jurisdiction over mergers. More generally, it stressed the significant contributions made by the concurrent enforcement of antitrust laws by state and federal agencies, and it opposed any plan for imposed allocation of authority. ${ }^{91}$

\section{Private Enforcement}

It is estimated that over $90 \%$ of antitrust litigation is by private parties. ${ }^{92}$ Both the statutory scheme and common law have combined to encourage antitrust litigants in certain ways, most notably through treble damages, joint and several liability, the no-contribution rule, and attorney fees for victorious plaintiffs. Perhaps in response, courts and Congress have adopted various techniques for making life more difficult for plaintiffs, such as the requirements for standing, ${ }^{93}$ antitrust injury, ${ }^{94}$ and evidentiary presumptions. ${ }^{95}$ While virtually no one is advocating for the elimination of private actions, the defense bar and their clients have long been interested in finding additional ways to tie the hands of plaintiffs.

Among the ideas raised during the AMC's hearings are: (1) reduction of the circumstances under which treble damages are mandatory (e.g., applying them only to more serious per se cases such as horizontal price fixing or allowing the court to decide after trial whether to multiply damages), (2) eliminating joint and several liability and the no-contribution rule (thereby reducing plaintiffs' leverage to gain favorable settlements), and (3) allowing fee-shifting so that the loser will pay the attorneys' fees for both sides (as opposed to the current rule that the liable defendant pays the plaintiffs' attorneys fees). ${ }^{96}$ Because a high proportion of plaintiffs' antitrust cases are brought on a contingent fee basis, any of these changes could affect

91. Am. Antitrust Inst., Comments of the American ANtitrust Institute Working GROUP ON ENFORCEMENT INSTITUTIONS (2005), available at http://www.amc.gov/public studies_fr28902/enforcement_pdf/050715_AAI_Enforc_Inst.pdf (last visited Feb. 7, 2006).

92. Ernest Gellhorn \& William E. Kovacic, Antitrust Law and Economics 462 (West Group 4th ed., 1994).

93. See generally Joseph P. Bauer, The Stealth Assault on Antitrust Enforcement: Raising the Barriers for Antitrust Injury and Standing, 62 U. PrTr. L. REV. 437 (2001).

94. Id.

95. Id.

96. See generally Civil Remedies Issues: Hearing Before the Antitrust Modernization Comm'n (2005), available at http://www.amc.gov/commission_hearings/civil_remedies_issues.htm (various statements). 
the cost-benefit analysis that determines whether a private case will be brought. For example, elimination of treble damages would reduce the payoff for a victory (and likely reduce the starting point for settlement negotiations). Thus, both plaintiff lawyers and consumersneither of whom are represented on the Commission-are concerned about what the AMC will recommend.

The AAI working group's comments argued against modifying the treble damage rule or making any procedural changes relating to civil antitrust remedies, other than to support the introduction of prejudgment interest. The working group supported continuation of awarding legal fees to a successful plaintiff and opposed changing the current rules relating to joint and several liability, contribution, and claim reduction. ${ }^{97}$

\section{Damages for Indirect Purchasers}

Ever since the Supreme Court's Illinois Brick Co. $v$ Illinois 98 opinion in 1977, there has been controversy over whether indirect purchasers (most often, classes of consumers) should be permitted to seek damages in antitrust cases. Roughly half of the consumers in the nation have the right to sue for such damages under what are known as State Illinois Brick Repealer laws. ${ }^{99}$

Various groups, including an ABA task force, have advocated some form of federal statute to provide for a single federal court to handle such cases, with (or perhaps without) preemption of state indirect purchaser laws. ${ }^{100}$ The AMC considers this complex issue so important that it allocated the subject two panels of five witnesses each. ${ }^{101}$

The AAI working group agreed that states need to be allowed to have laws to protect indirect purchasers. It recommended that there

97. See Am. Antitrust Inst., Comments of the American Antitrust Institute WorkING GROUP ON REMEDIES (2005), available at http://www.amc.gov/public_studies_fr28902/ remedies_pdf/AAI_Remedies.pdf (last visited Feb. 7, 2006).

98. 431 U.S. 720 (1977).

99. See generally Daniel R. Karon, "Your Honor, Tear Down That Illinois Brick Wall!" The National Movement Toward Indirect Purchaser Antitmust Standing and Consumer Justice, 30 WM. Mitchell L. Rev. 1351 (2004).

100. See State Indirect Purchaser Actions: Proposals for Reform: Hearing Before the Antitrust Modernization Comm'n (2005) (statement of Michaell Denger, Partner and Co-Chair, Antitrust \& Trade Regulation Practice Group, Gibson, Dunn \& Crutcher, LLP), available at http://www.amc.gov/commission_hearings/pdf/Denger.pdf.

101. Antitrust Modernization Comm'n, Commission Documents, Commission Hearings: Indirect Purchaser Actions, http://www.amc.gov/commission_hearings/indirect purchaser.htm. 
be an opportunity to evaluate the impact of the recently passed Class Action Fairness Act ${ }^{102}$ before any effort is made to enact further reform. ${ }^{103}$

\section{Single Firm Conduct}

Section 2 of the Sherman Act ${ }^{104}$ deals with monopolization and attempts to monopolize. In recent years, a variety of cases, headed by the Microsoft litigation and the Supreme Court's decision in Verizon Communications Inc. $v$. Trinko ${ }^{105}$ have inspired much conversation and literature concerning the question of what strategies by a single firm, acting alone, should be considered illegitimate. ${ }^{106}$ While it seems unlikely that the AMC will propose legislative revisions, it could attempt to provide expert guidance to courts and enforcers on standards for applying section 2 . This territory is hotly contested between traditionalists and conservatives, the former tending to support government intervention and the latter tending to support non-interference.

The AAI working group urged that the appropriate standards should be allowed to emerge through the normal playing out of the common law. ${ }^{107}$ Moreover, it does not interpret Trinko as having adopted any particular standard for treatment of refusals to deal. ${ }^{108}$ The working group supports the continuing development of the essential facilities doctrine. ${ }^{109}$

\section{Robinson-Patman Act}

The Robinson-Patman Act"10 ("R-P Act") outlaws certain types of price discrimination. The R-P Act is one of the laws that may facilitate control over power buyers, a phenomenon raising new levels of concern as giant retailers like Wal-Mart emerge. However, the AMC did

102. Pub. L. No. 109-2, 119 Stat. 4. (2005) (to be codified in scattered sections of 28 U.S.C.).

103. AM. ANTITRUST INST., supra note 97, at 18.

104. 15 U.S.C. $\$ 2(2000)$.

105. 540 U.S. 398 (2004).

106. For example, the DOJ and FTC have both scheduled hearings on single-firm conduct to begin in the spring of 2006. Press Release, Fed. Trade Comm'n, FTC and DOJ to Host Joint Public Hearings on Single-firm Conduct as Related to Competition, available at http://www.ftc.gov/opa/2005/11/unilateral.htm (last visited Mar. 23, 2006).

107. Am. Antitrust Inst., Comments of the American Antitrust Institute Working Group on Exclusionary Conduct 9-11 (2005), available at http://www.amc.gov/public studies_fr28902/exclus_conduct_pdf/050715_AAI-Exclus_Conduct_revd.pdf (last visited, Feb. 7, 2006).

108. Id. at 17-20.

109. Id. at 23.

110. 15 U.S.C. $\$ \S 13-13 b, 21 a(2000)$. 
not consider control over power buyers to be an issue worth considering in the process of modernizing. ${ }^{11}$ The R-P Act has rarely been enforced at the federal level during the past thirty years, but it remains in effect, helping to shape much domestic commerce, and is often the subject of private litigation. Small business-which is not represented on the Commission-adamantly supports continuation of the R-P Act and its active enforcement. It appears likely that the AMC will recommend revisions or outright repeal of the R-P Act. It will almost certainly recommend repeal of criminal jurisdiction under the R-P Act, which is rarely if ever utilized and has few if any known supporters.

The AAI working group urged that the R-P Act be reformed, but that it not be repealed, and suggested three ways in which it might be made more consistent with contemporary ideas about antitrust policy. ${ }^{112}$

\section{Mergers}

While not taking on major questions about the purpose or effectiveness of anti-merger laws, or even whether industrial concentration itself should still be the basis of legal presumptions, the Commission appears to be particularly interested in matters of process and administration. One major philosophical question may sneak in, however: what role should efficiencies play in a merger antitrust case. In particular, there could be discussion of whether to apply the standard of total welfare or consumer welfare, a technical but controversial issue that calls into play the values underlying antitrust law. ${ }^{113}$

The AAI working group recommended against any changes in the statutory framework of the merger laws, but urged that concentration should still play a major role in merger analysis. ${ }^{114}$ Most members of the working group supported the use of consumer welfare, as opposed to total welfare, as the standard for evaluating efficiency claims. ${ }^{115}$

111. For an overview of buying power, see generally Symposium, Buyer Power and Antitrust, 72 ANTITRust L.J. 505 (2005).

112. Am. Antitrust Inst., The Robinson-Patman Act Should Be Reformed, Not RePEALED 2 (2005), available at http://www.amc.gov/public_studies_fr28902/Robinson-patman_pdf/AAI_R_P_ACT.pdf (last visited Feb. 7, 2006).

113. See Foer, Goals of Antitrust, supra note 59, at 15-29.

114. Am. Antitrust Inst., Comments of the American ANTitrust Institute Working Group on MERGER ENFORCEMENT 3 (2005), available at http://www.amc.gov/public_studies _fr28902/merger_pdf/050715_AAI-Merger.pdf (last visited Feb. 7, 2006).

115. Id. at $9-10$. 


\section{Immunities and Exemptions}

The AMC could in theory have taken evidence on each item in the long list of statutory immunities and exceptions that limit the applicability of antitrust laws. It quickly became obvious that the Commission did not have the time or resources to do this and that such an undertaking would not likely lead to legislation. A different agenda emerged, in which the AMC would try to develop a framework for Congress to examine each new (or renewed) request for an immunity or exemption. As mentioned previously, consultants are preparing such a framework. ${ }^{116}$ Immunities and exemptions are generally the result of political power exercised on behalf of an industry, with the purpose of benefiting the industry rather than consumers. For this reason, any ammunition that would assist Congress in standing more firmly for the public interest would be desirable. It is conceivable that Congress might legislate a framework for itself that its members could point to when approached to support special interest antitrust legislation. This is potentially one of the most fruitful areas that the Commission has decided to pursue.

The AAI's working group urged creation of a methodology that, if adopted by Congress, could force Congress to closely examine certain questions before enacting special interest legislation. ${ }^{117}$

\section{Will Any of It Matter?}

The history of blue ribbon antitrust commissions in general does not suggest that the AMC's final Report will generate immediate legislative action. This particular Commission does not have politicians on board who are likely to champion enactment of the Report. Nor will the one politician who has shown interest, James Sensenbrenner, likely be in the privileged position as House Judiciary Committee Chairman, where his own leverage could be particularly useful in pushing forward a legislative agenda. This means that any legislative recommendations of the Commission will have to carry their own weight politically.

116. See supra text accompanying note 65 .

117. See generally Am. Antrtrust InSt., Comments of the Amerucan Antrtrust InstiTUTE Working Group on IMMUNITIES AND Exemptions (2005), available at http://www. amc.gov/public_studies_fr28902/immunities_exemptions_pdf/050715_AAI.pdf (last visited Feb. 6, 2006). The comments of the AAI Working Group on Immunities and Exemptions were drafted primarily by Warren Grimes (Southwestern University School of Law) and Darren Bush (University of Houston Law Center). Id. Professor Bush is one of the three consultants requested by the AMC to develop and present the framework idea. See supra text accompanying note 65 . 
Whether any legislative action will occur likely depends upon: (1) the substantive recommendations, (2) the style with which they are put forward, (3) the general political atmosphere at the time, and (4) who takes up the cause.

\section{The Substantive Recommendations}

It is too soon to know what substantive recommendations will be made. The previous section outlined some of the potential recommendations, e.g., a federal indirect purchaser law, modifications to the R-P Act, or revisions in the role of state or private enforcement. One can imagine that amending the R-P Act to knock out criminal jurisdiction would generate neither significant opposition nor excited support. However, a solution to the indirect purchaser problem has evaded legislators for a long time, and modifications to state or private enforcement or to the basic provisions of the R-P Act would likely stir up a hornet's nest of opposition.

\section{Style}

By style, I am referring to (1) quality of presentation, (2) emphasis, and (3) the handling of dissent. The quality of presentation will reflect organization and writing style. Will a committee style render the final Report readable only by devoted experts? Antitrust is a difficult enough topic to present to the lay public. Given the large number of topics and subtopics, many of which can only be of interest to experts, it will be a challenge to write something that will be read by more than a handful of antitrust lawyers and economists. There is also the matter of persuasiveness. How much information will be presented and how persuasive will the analysis be?

A related problem is that with so many different topics and subtopics in play, it may be difficult for a reader to see the forest for the trees. What message will come through? Will it be one that signals things are basically all right, but the common law needs to keep developing? Or will it be one that suggests that so many things are wrong that only severe surgery can save the economy? (I leave out a third scenario, which seems eminently desirable to me but most unlikely: that the Report will say that what is needed is more antitrust, aggressively and creatively applied, to keep an evolving economy flexible, innovative, and serving consumers with choice and competitive prices).

Finally, how will the Report handle dissent? Will individual or groups of Commissioners be inclined to write dissents? One route 
would be to suppress dissent by only reporting majority recommendations and findings. Another option would be to only make recommendations for which there is unanimity among the Commissioners. Since this would likely result in a very brief report, the real question is how much space to devote to disagreements. Should they merely be footnoted? Should dissenters be permitted adequate space to explain their reasons? The latter may offend majoritarians, but is likely to prove more useful in the long run. It would help to illuminate not only the existence and reasons for disagreement, but the degree of consensus that surrounds any given issue. A failure or refusal to incorporate conflicting information, interpretations, and recommendations into the Report would almost ensure that they will find their way into the public light through other means, which may only undermine the Report's credibility.

\section{The Political Scene}

The political landscape at the time the Report will be issued is an unknown. A set of legislative recommendations decided upon in the expectation of a conservative Republican Congress and White House would very likely have a lesser chance of enactment if elections develop a different picture. Unpredictable economic circumstances, such as a depression or large-scale corporate scandals, could also have a major impact. Depending upon the precise recommendations, various interest groups can be expected to push back in the normal political course of events.

\section{Who Will Take Up the Cause?}

I was asked by one of the Commissioners, "Why are the states, the plaintiffs' bar, and consumers so intensely concerned about what we are doing? All we can do is make recommendations."

The answer is that the Commission can start the ball rolling, and no one knows where the momentum will take it. Lobbyists worry about a bill being introduced because one day the bill (originally no more than a recommendation) may become law, and many resources will have to be spent trying to influence the course of the bill, whose future passage, defeat, or form cannot prudently be taken for granted.

We do not know who will be making decisions about antitrust two, five, or ten years from now, but ideas once put into circulation by a credible blue ribbon commission might find champions in the future. 
Moreover, the test of a blue ribbon commission's effectiveness is not limited to legislation. The AMC's Report could influence the other institutions that frequently play an even more important role within the antitrust community-the federal and state enforcement agencies, the courts, the antitrust bar, and academics.

As the AMC team comes back onto the field after a somewhat slow first half, the antitrust crowd watches eagerly, hopeful for a fair, spirited, and high quality contest of ideas. 
